\title{
Molecular characterization of Portuguese populations of the pinewood nematode Bursaphelenchus xylophilus using cytochrome $b$ and cellulase genes
}

\author{
V. Valadas ${ }^{1}$, M. Laranjo ${ }^{2,3}$, M. Mota ${ }^{1}$ and S. Oliveira ${ }^{2 *}$ \\ ${ }^{1}$ NemaLab-ICAAM and Departamento de Biologia, Universidade de \\ Évora, Évora, Portugal: ${ }^{2}$ Lab. Microbiologia do Solo-ICAAM and \\ Departamento de Biologia, Universidade de Évora, Évora, Portugal: ${ }^{3}$ IIFA \\ (Instituto de Investigação e Formação Avançada), Universidade de Évora, \\ Évora, Portugal
}

(Received 14 February 2012; Accepted 5 September 2012)

\begin{abstract}
Bursaphelenchus xylophilus is the causal agent of pine wilt disease and a worldwide pest with high economic impact. Since its first diagnosis in Portugal in 1999, it has been subjected to quarantine measures with impact on forest health and ecosystem stability, significantly affecting international trade of wood products. The disease was detected in the north and centre of continental Portugal and, since 2008, the whole country has been considered an affected area. Recently, it was detected in Madeira Island. In order to avoid new outbreaks, it has become of major importance to understand the patterns of spread, introduction points and to characterize the new populations from continental Portugal and Madeira Island. Mitochondrial cytochrome $b(c y t b)$ and parasitic cellulase gene sequences were used to evaluate the genetic relationships among isolates that could indicate possible origins of the new outbreaks. Portuguese isolates were compared with isolates from USA, China, Japan and South Korea, in order to investigate possible infection pathways and disease spread patterns in Portugal. Phylogenetic trees based on both genes show that Portuguese isolates group with Asian isolates. Isolates from USA are in a separate position in both gene trees. However, the phylogenetic tree based on the cellulase gene sequences shows higher differentiation among Portuguese isolates than that of $c y t b$. These results agree with those previously obtained using inter-simple sequence repeats (ISSR). This was the first study to use cytb and cellulase genes to characterize pinewood nematode (PWN) populations. This study suggests that cellulase is a better marker than $c y t b$ to study genetic diversity in B. xylophilus.
\end{abstract}

\section{Introduction}

The pinewood nematode (PWN), Bursaphelenchus xylophilus (Steiner \& Buhrer, 1934; Fuchs, 1937), is the causative agent of pine wilt disease (PWD). Indigenous in North America, this nematode is widespread in natural coniferous forests in Canada and the USA (Sutherland \& Peterson, 1999) without representing an economic problem to native pine forests. In non-native forest ecosystems, namely in Asian countries such as Japan, China, South Korea and Taiwan (for a review see Vicente

*E-mail: ismo@uevora.pt 
et al., 2012), the PWN is one of the most feared pests and pathogens due to its impact on forest health, natural ecosystem stability and international trade (Vicente et al., 2012). The effects of the PWN on the global ecosystem and natural biodiversity are irreversible (Kiyohara \& Bolla, 1990; Suzuki, 2002). The PWN and several other Bursaphelenchus species have been intercepted from packaging and wood products in several countries, e.g. Austria (Tomiczek et al., 2003), China (Gu et al., 2006), Finland (Tomminen et al., 1991) and Germany (Braasch et al., 2001), and, more recently, in packaging wood imported from countries considered free of this pest, such as Brazil, Belgium, Italy and Spain (Gu et al., 2006). This has increased the need to avoid the spread of this pathogen outside North America.

Bursaphelenchus xylophilus was reported for the first time in Europe in Portugal in 1999, from dead maritime pine (Pinus pinaster) trees located in the Setúbal Peninsula, $30 \mathrm{~km}$ SE of Lisbon (Mota et al., 1999). Until 2008, the PWN was confined to the Setúbal Peninsula, but despite all efforts made by the Portuguese authorities, the disease spread to new areas in 2008 (Rodrigues, 2008), and was recently detected in Madeira Island, $1000 \mathrm{~km}$ SW of continental Portugal (Fonseca et al., 2010; Vicente et al., 2012), as well as in Spain (Abelleira et al., 2011; Robertson et al., 2011). Thus, it is of vital importance to determine the origin of the new isolates and understand their routes of spread, in order to prevent further infections in Europe. Molecular markers displaying enough genetic polymorphism could be useful for understanding the epidemiology of this disease and its dissemination pathways. DNA-based techniques developed during the past decades provide an attractive solution to nematode identification. In spite of that, determination of intraspecific variability is difficult. Due to the high copy number in individual cells, lack of recombination and strict maternal inheritance, mitochondrial genes (mtDNA) are known to be an excellent marker for the study of phylogenetic relationships.

In recent years, mitochondrial genes have been used as markers to study intraspecific variation (Madani et al., 2010) and the genetic relationships among Peruvian and Canadian populations of Globodera pallida in order to identify the origin of new populations (Picard et al., 2007; Plantard et al., 2008; Madani et al., 2010). For example, mtDNA cytochrome $b(c y t b)$ gene sequences allowed the determination of the origin of new $G$. pallida populations (Plantard et al., 2008), which makes this a possible marker to be tested in the study of B. xylophilus intraspecific variability.

PWN is an unusual plant parasite, as it is a parasite of the aboveground parts of trees, migrating through plant tissues and never entering the soil. It is a fungal feeder that uses an insect vector, a cerambycid beetle, particularly Monochamus spp. (Akbult \& Stamps, 2011), for transmission from one tree to another, implying that it should contain a set of parasitic genes distinct from those of the major plant parasitic nematodes (Kikuchi, 2008). The only other example of a similar plant parasite within this genus (containing nearly 100 species) is $B$. cocophilus, which parasitizes coconut and palm trees in Central and South America, and is the causal agent of 'red ring disease'.
Plant cell walls are mainly made up of cellulose and, consequently, cellulases (endo- $\beta-1,4$-glucanases) are cell wall degrading enzymes, produced by many plant pathogenic nematodes, such as B. xylophilus (Smant et al., 1998; Jones et al., 2005; Zhao \&Lin, 2005; Kikuchi et al., 2007). Previous studies of Ma et al. (2011), using RNA interference to analyse the function of the endo- $\beta-1,4-$ glucanase gene of $B$. xylophilus, show that the propagation and dispersal ability of this nematode decreased when the endo- $\beta$-1,4-glucanase gene was silenced. Bursaphelenchus $x y l o p h i l u s$ uses a stylet to penetrate the plant cell wall. This stylet is associated with oesophageal glands, which produce secretions containing cellulases. Endogenous cellulase genes have been identified in obligatory plantparasitic nematodes, such as Heterodera, Globodera and Meloidogyne species (Smant et al., 1998; Rosso et al., 1999; Goellner et al., 2000). The proteins encoded by these genes belong to the glycosyl hydrolase family (GHF), which in B. xylophilus are more similar to fungal GHF cellulases, suggesting acquisition by horizontal gene transfer from fungi (Jones et al., 2005; Kikuchi et al., 2007; Xie et al., 2009). Sequence analysis of the cellulase genes allowed species identification as well as intraspecific variability evaluation within the genus Bursaphelenchus (Cheng et al., 2008, 2010).

The aim of the present study was to characterize Portuguese populations of the PWN, B. xylophilus, using $c y t b$ and cellulase gene sequences. These sequences were used for comparative phylogenetic analyses of PWN populations collected from different geographic locations from continental Portugal and Madeira Island. Cytb and cellulase sequences were compared with sequences from B. xylophilus from other countries, such as USA, Japan, China and South Korea, in order to understand the possible origin of the new outbreaks of the disease in continental Portugal and Madeira Island.

\section{Materials and methods}

Nematode sampling and cultures

The present study used 19 B. xylophilus isolates from Portugal (continental and Madeira Island) (fig. 1) which were compared with several foreign isolates: three US isolates, two South Korean, three Japanese and four Chinese (table 1). Madeira Island isolates were provided by the Nematology Lab, IMAR-CMA (Department of Life Sciences, University of Coimbra), and continental Portugal isolates were provided by AFN (National Forest Authority) from the national surveys conducted every year. One B. mucronatus ( $\mathrm{BmPt} 0$ ) Portuguese isolate was also used. Each isolate was obtained from a wood sample collected from one tree. Nematode cultures were maintained in the laboratory in barley grown with Botrytis cinerea (Y. Mamiya, pers. comm.). Nematodes were extracted using a modified Baermann funnel technique (Southey, 1986). Prior to DNA extraction, nematodes were collected and concentrated in a $1.5-\mathrm{ml}$ microtube (Eppendorf) in a minimal amount of water.

\section{DNA extraction}

Genomic DNA was extracted from a suspension of $50 \mu \mathrm{l}$ with more than 10,000 nematodes from each isolate. 
DNA was extracted with the JETQUICK Tissue DNA Spin Kit extraction kit (Genomed, Löhne, Germany), according to the manufacturer's protocol. DNA was used for sequence analysis of $c y t b$ and cellulase genes. Nematode DNA was kept at $-20^{\circ} \mathrm{C}$ for further use.

\section{Sequencing of cytochrome $\mathrm{b}$ and cellulase genes}

For $c y t b$ amplification, $50 \mu \mathrm{l}$ polymerase chain reactions (PCR) contained $1 \times$ PCR buffer (Fermentas, Vilnius, Lithuania), $1.5 \mathrm{mM} \mathrm{MgCl}_{2}$ (Fermentas), $0.2 \mathrm{mM}$ each deoxyribonucleotide (dNTP) (Fermentas), $0.4 \mu \mathrm{M}$ of each primer (STABvida, Lisboa, Portugal), 0.05 units of recombinant Taq DNA polymerase (Fermentas) and $5 \mu \mathrm{l}$ template DNA (10-20 ng). Primers were designed based on the full mitochondrial sequence of B. xylophilus (isolate BxPt15SC, accession number JQ429761; A. Amorim, pers. comm.): BxCYB F (5'-AAA TAG AAT TTT TGT TTT TGG TAT-3') and BxCYB R (5'-TGT GAA AAA TCT ATA AGA CCT AAA CTT-3'). Primers were designed to amplify the entire $c y t b$ gene sequence. The PCR program consisted of an initial denaturation step of $3 \mathrm{~min}$ at $95^{\circ} \mathrm{C}$, followed by 30 cycles of denaturation at $95^{\circ} \mathrm{C}$ for $30 \mathrm{~s}$, annealing at $44^{\circ} \mathrm{C}$ for $30 \mathrm{~s}$ and extension at $72^{\circ} \mathrm{C}$ for $1 \mathrm{~min} 30 \mathrm{~s}$. The final

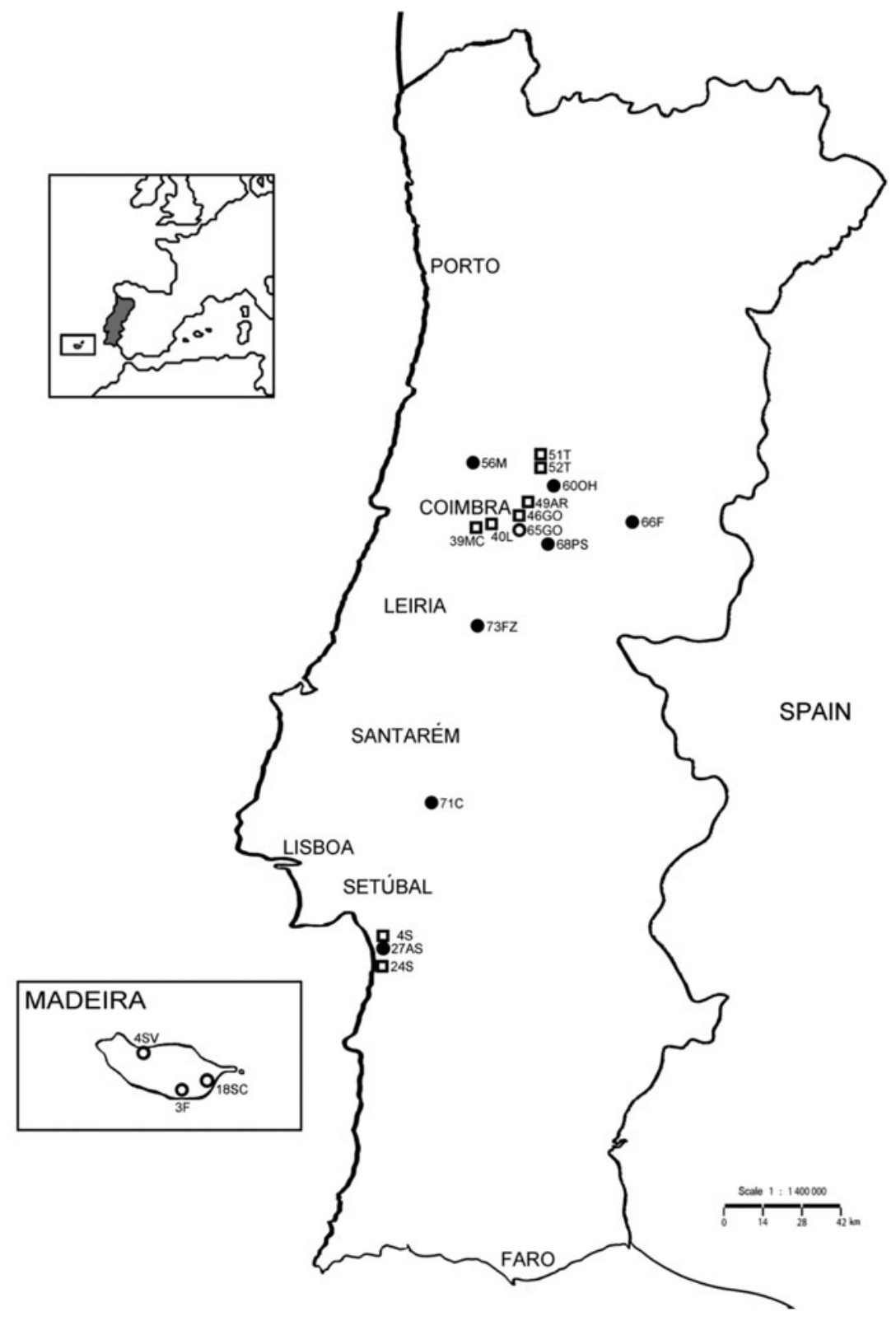

Fig. 1. Map of the geographical distribution of B. xylophilus in continental Portugal and Madeira Island, showing the sampling sites of isolates collected until 2008 and in 2009-2010. Isolate codes and symbols are shown in table 1 (until 2008 口, 2009 •, 2010 o). 
Table 1. List of B. xylophilus isolates, location, year of collection, map symbol/code and accession numbers of cellulase and cytb sequences (until 2008 口, $2009 \bullet$, 2010 O). Accession numbers for sequences determined in the present study are shown in bold.

\begin{tabular}{|c|c|c|c|c|c|c|}
\hline \multirow[b]{2}{*}{ Country } & \multirow[b]{2}{*}{ Location } & \multirow[b]{2}{*}{ District } & \multirow[b]{2}{*}{ Year of collection } & \multirow[b]{2}{*}{ Map symbol/Code } & \multicolumn{2}{|c|}{ Accession numbers } \\
\hline & & & & & Cellulase & $c y t b$ \\
\hline \multirow[t]{16}{*}{ Portugal } & Alcácer do Sal & Setúbal & 2005 & $\square \mathrm{BxPt} 4 \mathrm{~S}$ & - & JQ423188 \\
\hline & Grândola & Setúbal & 1999 & $\square \mathrm{BxPt} 24 \mathrm{~S}$ & JQ423161 & JQ423189 \\
\hline & Alcácer do Sal & Setúbal & 2009 & BxPt27AS & - & JQ423190 \\
\hline & Miranda do Corvo & Coimbra & 2008 & $\square \mathrm{BxPt39MC}$ & JQ423162 & - \\
\hline & Lousã & Coimbra & 2008 & $\square \mathrm{BxP} 440 \mathrm{~L}$ & JQ423163 & - \\
\hline & Góis & Coimbra & 2008 & $\square \mathrm{BxP} 446 \mathrm{GO}$ & JQ423164 & - \\
\hline & Arganil & Coimbra & 2008 & $\square \mathrm{BxPt49AR}$ & JQ423165 & - \\
\hline & Tábua & Coimbra & 2008 & $\square \mathrm{BxPt51T}$ & JQ423166 & - \\
\hline & Tábua & Coimbra & 2008 & $\square \mathrm{BxPt52T}$ & JQ423167 & - \\
\hline & Mealhada & Coimbra & 2009 & - BxPt56M & - & JQ423191 \\
\hline & Oliveira do Hospital & Coimbra & 2009 & - BxPt60OH & - & JQ423192 \\
\hline & Góis & Coimbra & 2010 & O BxPt65GO & - & JQ423193 \\
\hline & Fundão & Castelo Branco & 2009 & - BxPt66F & JQ423168 & JQ423194 \\
\hline & Pampilhosa da Serra & Coimbra & 2009 & - BxPt68PS & JQ423169 & - \\
\hline & Coruche & Santarém & 2009 & - BxPt71C & JQ423170 & JQ423195 \\
\hline & Ferreira do Zêzere & Santarém & 2009 & - BxPt73FZ & JQ423171 & JQ423196 \\
\hline \multirow[t]{3}{*}{ Portugal (Madeira) } & São Gonçalo & Funchal & 2010 & O BxMad3F & JQ423172 & JQ423197 \\
\hline & São Vicente & São Vicente & 2010 & o BxMad4SV & JQ423173 & - \\
\hline & Santa Cruz & Santa Cruz & 2010 & o BxMad18SC & JQ423174 & JQ423198 \\
\hline \multirow[t]{4}{*}{ China } & Jiansu Province & & & BxChJs & JQ423175 & JQ423199 \\
\hline & Jiangxi Province & & & BxChJx & JQ423176 & JQ423200 \\
\hline & Shandong Province & & & $\mathrm{BxChHB}$ & JQ423178 & - \\
\hline & Shandong Province & & & BxChSD & JQ423177 & JQ423201 \\
\hline \multirow[t]{3}{*}{ Japan } & Unknown & & & BxJS10 & JQ427179 & JQ423202 \\
\hline & Unknown & & & BxJT4 & JQ423180 & JQ423203 \\
\hline & Unknown & & & BxJKa4 & JQ423181 & - \\
\hline \multirow[t]{2}{*}{ South Korea } & Unknown & & & BxKAs & JQ423182 & JQ423204 \\
\hline & Unknown & & & BxKBG & JQ423183 & JQ423205 \\
\hline \multirow[t]{3}{*}{ USA } & Unknown & & & BxUSA345 & JQ423184 & - \\
\hline & Unknown & & & BxUSA618 & JQ423185 & JQ423206 \\
\hline & Unknown & & & BxUSA745 & JQ423186 & JQ423207 \\
\hline
\end{tabular}

- , No sequence available. 
extension step was performed at $72^{\circ} \mathrm{C}$ for $5 \mathrm{~min}$. PCR products were electrophoresed in 1\% agarose gels, stained with ethidium bromide and sequenced by STABvida, Portugal.

For amplification of the cellulase gene, primers ENG00s (5'-TCT AAA ATG AAG TCT CTT GTG-3') and ENG00a (5'-AGT CCT CTA AGC ATC GTC-3') (Kikuchi et al., 2004) were used. PCR amplifications were conducted in $50 \mu \mathrm{l}$ PCR reactions containing $1 \times$ PCR buffer (Fermentas), $2 \mathrm{mM} \mathrm{MgCl}_{2}$ (Fermentas), $0.2 \mathrm{~mm}$ each dNTP (Fermentas), $10 \mathrm{pmol}$ of each primer (STABvida), 1.25 units of recombinant Taq DNA polymerase (Fermentas) and $5 \mu \mathrm{l}$ template DNA (10-20 ng). The PCR program consisted of an initial $3 \mathrm{~min}$ denaturation at $95^{\circ} \mathrm{C}$, followed by 30 cycles of denaturation at $94^{\circ} \mathrm{C}$ for $1 \mathrm{~min}$, annealing at $50^{\circ} \mathrm{C}$ for $1 \mathrm{~min}$ and extension at $72^{\circ} \mathrm{C}$ for $1 \mathrm{~min}$. The last step was performed at $72^{\circ} \mathrm{C}$ for $5 \mathrm{~min}$. PCR products were visualized in 1\% agarose gels stained with ethidium bromide, purified with MinElute Gel Extraction Kit (Qiagen, Hilden, Germany) and quantified using Quant-iT dsDNA High-Sensitivity Assay Kit (Invitrogen, Paisley, UK). Gel-purified PCR products were ligated into pGEM-T Easy Vector (Promega, Madison, Winconsin, USA) and transformed into Escherichia coli strain JM109 competent cells (Promega) according to the manufacturer's instructions. Plasmids were purified from two or three positive clones using the GeneJET Plasmid Miniprep Kit (Fermentas) and the cellulase gene was obtained by restriction with the endonuclease EcoRI (Fermentas). The gel band corresponding to the cellulase gene was purified using MinElute Gel Extraction Kit (Qiagen) and sequenced by STABvida, Portugal.

\section{Phylogenetic analysis of cytochrome $\mathrm{b}$ and cellulase sequences}

Multiple sequence alignments of $c y t b$ and cellulase nucleotide sequences were assembled using the ClustalW algorithm as implemented in BioEdit version 7.1.3.0 (Hall, 1999), under default alignment parameters. Using MEGA5 version 5.05 (Tamura et al., 2011) phylogenetic relationships between isolates were reconstructed by neighbour-joining (Saitou \& Nei, 1987) and maximum likelihood (ML) methods, using nucleotide sequences. The best-fitting evolutionary model of nucleotide substitutions was determined. Gaps or indels were treated using the complete deletion option in MEGA5. Clades from the ML tree were supported by bootstrap analysis (Felsenstein, 1985) with 100 replicates.

\section{Results}

\section{Phylogenetic analysis of the cytochrome $\mathrm{b}$ gene}

A PCR product of approximately $1200 \mathrm{bp}$, containing the partial sequence of $c y t b$ was obtained and sequenced (accession numbers in table 1) using 11 Portuguese isolates of $B$. xylophilus, nine foreign isolates from China, Japan, South Korea and USA, and one B. mucronatus (BmPt0 accession number JQ655730) Portuguese isolate. Other nematodes, such as Caenorhabditis elegans and Heterorhabditis bacteriophora were also included in the analysis and the fungus Rhizopus oryzae (accession numbers in table 2) was used as outgroup. Only a few polymorphisms were found among B. xylophilus isolates. One major cluster was obtained that includes all Portuguese and foreign isolates (bootstrap value of $70 \%$ ), with the exception of US isolates (BxUSA618 and BxUSA745) and a Japanese isolate (BxJS10) (fig. 2) (bootstrap support of 99\%). However, the similarities of these three isolates with the Portuguese and foreign isolates from the major cluster, still varies between 98 and 99\%. No differentiation was obtained between geographical isolates from Portugal. All Portuguese isolates group with Asian isolates from China, South Korea and Japan (with the exception of BxJS10).

\section{Phylogenetic analysis of the cellulase gene}

Fourteen Portuguese and 12 foreign isolates from China, Japan, South Korea and USA of B. xylophilus, as well as one B. mucronatus (BmPt0) Portuguese isolate, were used to generate a PCR product of approximately $950 \mathrm{bp}$, containing the partial sequence of the cellulase gene that was sequenced. Accession numbers are listed in table 1. Phylogenetic analyses were performed by comparing our sequences with others available in public databases, such as those from B. xylophilus eng 1, eng 2 and eng 3, from fungi ( $R$. oryzae, Mucor circinelloides, Neurospora crassa, Fusarium oxysporum) and from insects (Phaedon cochleariae, Apriona germari); the bacterial sequence from the bacterium Cellvibrio japonicus was used as an outgroup (table 2). One major cluster was obtained which contains all B. xylophilus isolates (fig. 3) (bootstrap support of 96\%), sharing similarities between 98 and $99 \%$. Inside this major cluster, there is another one, which includes all Portuguese isolates collected since the first detection in 1999 until the recent (2010) detection in Madeira Island (bootstrap 65\%) and also isolates from China (BxChJs, BxChSD, BxChHB), South Korea (BxKAs, BxKBG), Japan (BxJT4, BxJS10) and USA (BxUSA745). There is no clear geographic differentiation between Portuguese isolates collected until 2008 (during the time that the disease was restricted to Setúbal Peninsula) and after this date (new outbreaks in the centre and north of Portugal and in Madeira Island). Isolates BxPt66F and BxJS10 group together inside the previous cluster as well

Table 2. Cellulase and cytb accession numbers of reference organisms/strains used for phylogenetic analysis.

\begin{tabular}{lll}
\hline & \multicolumn{2}{c}{ Accession number } \\
\cline { 2 - 3 } Species & cellulase & \multicolumn{1}{c}{ cytb } \\
\hline Bursaphelenchus xylophilus eng 1 & AB179541 & - \\
B. xylophilus eng 2 & AB179542 & - \\
B. xylophilus eng 3 & AB179543 & - \\
Caenorhabditis elegans & - & AY171189 \\
Heterorhabditis bacteriophora & - & EF043402 \\
Mucor circinelloides & AB175928 & - \\
Rhizopus oryzae & AB047927 & AY863212 \\
Neurospora crassa & BX284763 & - \\
Fusarium oxysporum & L29381 & \\
Apriona germari & AY162317 & - \\
A. germari & AY451327 & - \\
Phaedon cochleariae & Y17907 & - \\
Cellvibrio japonicus & X52615 & - \\
\hline
\end{tabular}




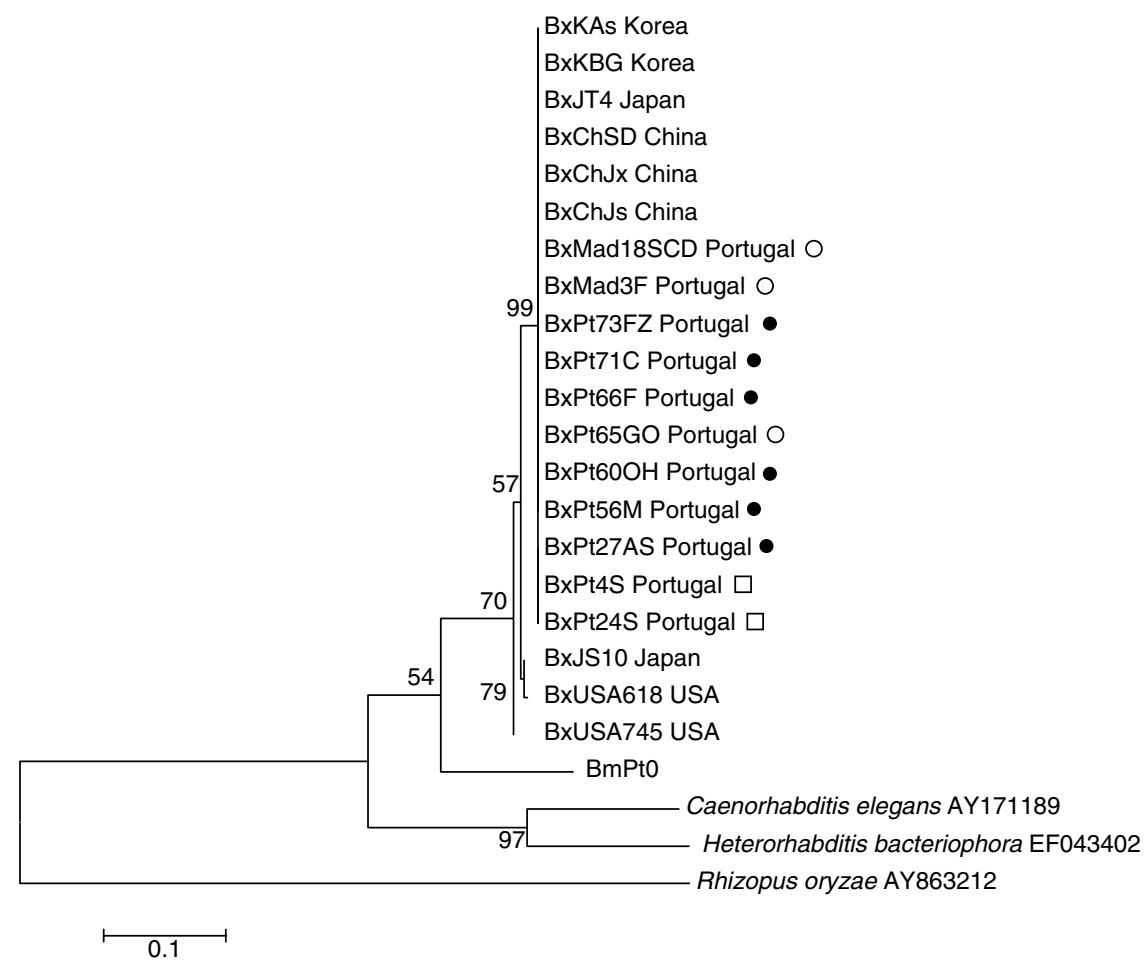

Fig. 2. Maximum likelihood $c y t b$ phylogenetic tree based on nucleotide sequences of 20 isolates of B. xylophilus and reference strains (alignment length $387 \mathrm{bp}$ ). Percentage bootstrap is indicated on internal branches (100 replicates); scale bar indicates 0.1 substitutions per site. The Tamura \& Nei model (Tamura \& Nei, 1993) was used. Symbols represent isolates collected until $\square, 2008 ; \bullet, 2009$ and $0,2010$.

as BxPt24S, BxPt49AR and BxChJs. Grouping with the major cluster, are isolates BxUSA345, BxUSA618, BxJKa4 and $B x C h J x$, the most distant related isolates being BxJKa4 and BxUSA618. The presence of isolates from China, Japan and USA in different branches of the phylogenetic tree points to the existence of intraspecific variability. Bx-eng-1 sequence groups with Portuguese and foreign isolates (sequence identity of $99-100 \%$ ). Grouping apart from this cluster there are two sequences, Bx-eng-2 and Bx-eng-3 that probably represent different cellulase genes, as already proposed by Kikuchi and co-authors (2004). Bursaphelenchus xylophilus cellulase sequences share similarities of between 49 and $62 \%$ with the fungi $R$. oryzae and $M$. circinelloides, and of $49-66 \%$ with N. crassa and F. oxysporum. The similarity between B. xylophilus and fungal cellulases $(49-66 \%)$ is higher than that between B. xylophilus and the bacterium C. japonicus sequences $(36-41 \%)$.

\section{Discussion}

Following the first report (Mota et al., 1999), B. xylophilus was successfully restricted to the Setúbal Peninsula until 2008. In 2008, the nematode was detected in new outbreak spots in central and northern regions of the country (Rodrigues, 2008) and, more recently, in one of the islands of the Madeira archipelago (Fonseca et al., 2010).

The first study conducted to understand the genetic diversity of Portuguese populations was performed by
Vieira et al. (2007) using 24 isolates from the initial affected area. In this study, using random amplification of polymorphic DNA (RAPD) analysis, the authors showed that there was almost no genetic diversity among Portuguese isolates and that these grouped with a Chinese isolate instead of an isolate from the USA.

In a recent study using the inter-simple sequence repeats (ISSR) technique and intergenic spacer (IGS) sequences, 34 isolates representing the different geographic locations of B. xylophilus in Portugal, from 1999 to 2010, were analysed, to understand the pathways of spread and the introduction point of the disease (Valadas et al., 2012). This study was the first to use a significant number of B. xylophilus isolates from continental Portugal and Madeira Island as well as foreign isolates. The ISSR technique proved to be useful in determining genetic diversity of Portuguese B. xylophilus isolates.

ISSR fingerprints showed high genetic variability among Portuguese isolates, except for those obtained prior to 2008. Until 2008, B. xylophilus populations found in continental Portugal showed low genetic diversity, pointing to a single introduction, probably from Asia, in agreement with the results of Vieira et al. (2007). In contrast, recent populations from continental Portugal (2009-2010) and Madeira show high genetic diversity, suggesting multiple introductions from different origins.

In the present study, $c y t b$ and cellulase genes were used, with the aim of understanding the genetic diversity of 


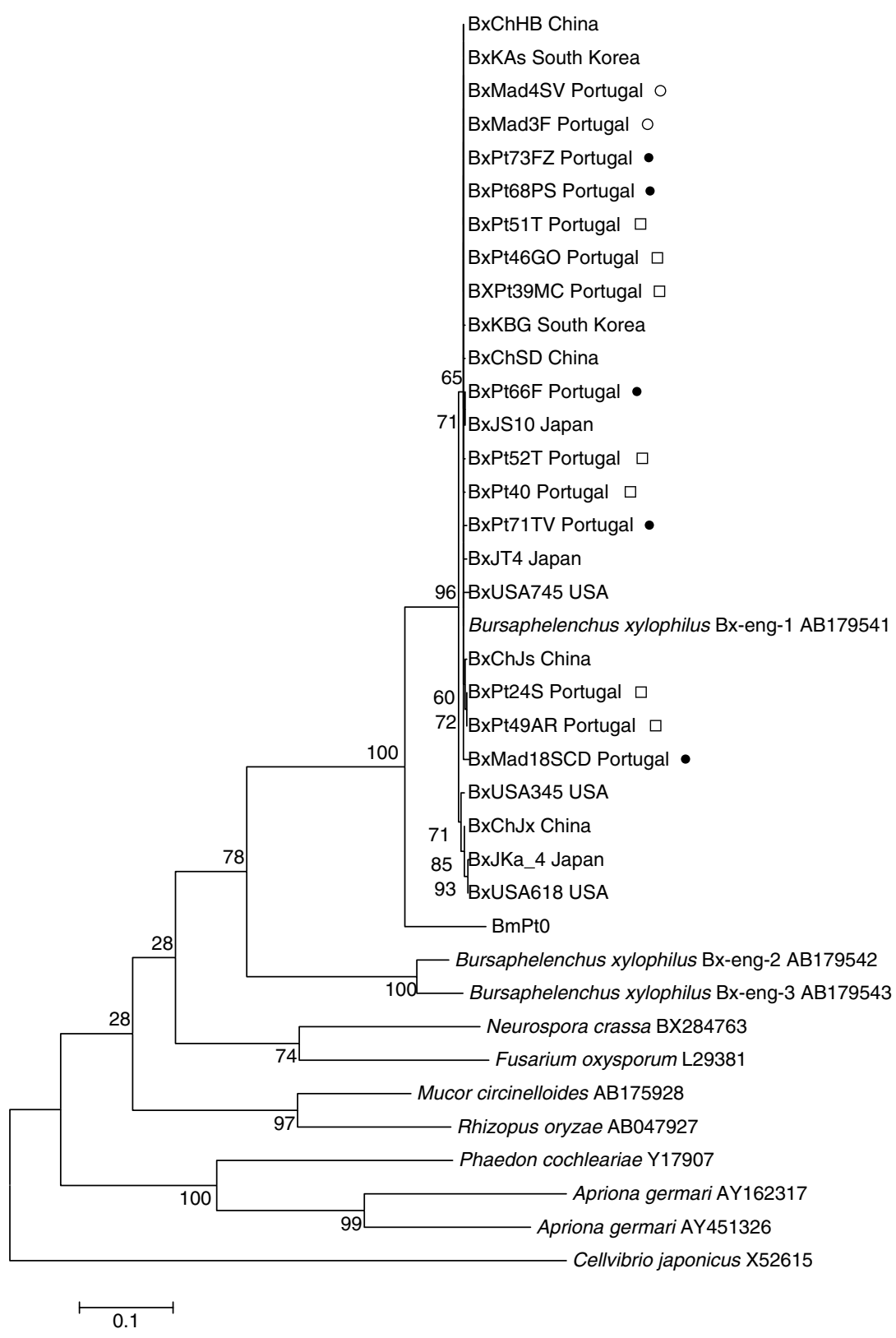

Fig. 3. Maximum likelihood cellulase phylogenetic tree based on nucleotide sequences of 26 isolates of B. xylophilus and reference strains (alignment length $787 \mathrm{bp}$ ). Percentage bootstrap is indicated on internal branches (100 replicates); scale bar indicates 0.1 substitutions per site. The Kimura two-parameter model (Kimura, 1980) was used. Symbols represent isolates collected until $\square, 2008 ; \bullet, 2009$ and $0,2010$.

Portuguese populations, comparing them with foreign isolates from Japan, China, South Korea and USA. Our results agree with previous studies (Vieira et al., 2007; Valadas et al., 2012) in suggesting a possible Asian origin for Portuguese isolates.

Due to the high copy number in individual cells, the lack of recombination and the strict maternal inheritance, mitochondrial DNA (mtDNA) seems to be a potential marker to study genetic diversity and characterize populations from the same organism (Madani et al., 2010). In order to characterize populations and infer the origin of Portuguese isolates, the $c y t b$ gene was used in the present study. Bursaphelenchus xylophilus populations were characterized and, although the intraspecific diversity was very low, it was possible to confirm the previously suggested similarity of Portuguese and Asian isolates (fig. 2) (Vieira et al., 2007; Valadas et al., 2012). However, the low resolution obtained with $c y t b$ prompted us to use the cellulase gene, in an attempt to find a better genetic marker.

In the cellulase phylogenetic tree (fig. 3), Portuguese and foreign isolates group together in the same large 
cluster, which also includes the Bx-eng-1 sequence, previously obtained by Kikuchi and collaborators (2004). Inside this major clade, it is possible to observe some genetic diversity among isolates, showing that cellulase sequences are more discriminative to study intraspecific variations than $c y t b$ sequences. However, no clear grouping of Portuguese isolates according to their geographic location or year of collection is observed. The clustering of Portuguese isolates with different Asian isolates may suggest more than one introduction in Portugal of the PWN of Asian origin.

Figure 3 shows that B. xylophilus cellulases are more similar to the fungal cellulases from $R$. oryzae and $M$. circinelloides than to cellulases from insects or bacteria. This large group clusters first with $B$. mucronatus and then with Bx-eng-2 and Bx-eng-3, which seem to code for different cellulase genes (Kikuchi et al., 2004). Previous phylogenetic studies had already suggested that cellulase genes from nematodes may have been acquired from different microbial donors (Dieterich \& Sommer, 2009). Cellulases from plant parasitic Tylenchida, such as Globodera, Heterodera and Meloidogyne (cyst and rootknob nematodes) are from the GHF5 family of cellulases and seem to have been acquired by lateral gene transfer (LGT) from bacteria (Kikuchi, 2008). On the other hand, our results agree with other studies, which have suggested that B. xylophilus might have acquired a different family of cellulases, GHF45, from fungi by LGT (Kikuchi et al., 2004). This may be related to the fact that this species is solely a fungal feeder, transmitted by insect vectors to dead or dying trees during oviposition. Although B. xylophilus, as well as cyst and root-knob nematodes, belongs to the Tylenchida, their cellulases are not directly related. GHF45 cellulases are exclusively produced by Bursaphelenchus species.

This study was the first to use cellulase and $c y t b$ genes to characterize PWN populations. However, contrary to other studies, our results suggest that cellulase is a better marker to study genetic diversity among populations of B. xylophilus.

The recent release of the full B. xylophilus genome sequence (Kikuchi et al., 2011) may unravel new molecular markers to study intraspecific variability to determine pathways of disease spread and follow the evolution of introduced isolates. Furthermore, recent studies on mitochondrial DNA sequencing (A. Amorim, pers. comm.) should be considered to evaluate the potential of mtDNA and its different genes for phylogenetic and biodiversity studies.

\section{Acknowledgements}

This research was supported by the EC 7th 324 Framework project REPHRAME (KBBE.2010.1.4-09, 'Analysis of the potential of the pine wood nematode (Bursaphelenchus xylophilus) to spread, survive and cause pine wilt in European coniferous forests in support of EU plant health policy') and by a national project from the Portuguese National Forestry Authority (AFN, Autoridade Florestal Nacional), 'O nemátode da madeira do pinheiro (NMP), Bursaphelenchus xylophilus'. This work was also funded by FEDER (Funds through the
Operational Programme for Competitiveness Factors) COMPETE and National Funds through FCT (Fundação para a Ciência e a Tecnologia) under the Strategic Project PEst-C/AGR/UI0115/2011. We would like to thank Dr Bouang Zhao, Nanjing Forestry University, China; Dr Hyerim Han, Korea Forest Research Institute, South Korea; Dr K. Futai, Kyoto University, Japan; Dr Robin Giblin-Davis, University of Florida, USA and Isabel Abrantes, Coimbra University, Portugal, for providing nematode cultures of B. xylophilus. We thank Filipe Pereira, Cláudia Moreira, Barbara van Asch and António Amorim for providing sequence data of B. xylophilus cytochrome $b$. We would like to thank Pedro Barbosa, for providing the map used in fig. 1. This paper is a portion of the PhD dissertation of the first author, who is supported by a doctoral scholarship from FCT (SFRH/BD/22086/2005).

\section{References}

Abelleira, A., Picoaga, A., Mansilla, J.P. \& Aguin, O. (2011) Detection of Bursaphelenchus xylophilus, causal agent of pine wilt disease on Pinus pinaster in Northwestern Spain. EPPO Bulletin 39, 344.

Akbult, S. \& Stamps, W.T. (2011) Insect vectors of the pinewood nematode: a review of the biology and ecology of Monochamus species. Forest Pathology 42, 89-99.

Braasch, H., Tomiczek, C., Metge, K., Hoyer, U., Burgermeister, W., Wulfert, I. \& Schonfeld, U. (2001) Records of Bursaphelenchus spp. (Nematoda, Parasitaphelenchidae) in coniferous timber imported from the Asian part of Russia. Forest Pathology 31, 129-140.

Cheng, X.Y., Cheng, F.X., Xu, R.M. \& Xie, B.Y. (2008) Genetic variation in the invasive process of Bursaphelenchus xylophilus (Aphelenchida: Aphelenchoididae) and its possible spread routes in China. Heredity 100, 356-365.

Cheng, X.Y., Dai, S.M., Xiao, L. \& Xie, B.Y. (2010) Influence of cellulase gene knockdown by dsRNA interference on the development and reproduction of the pine wood nematode, Bursaphelenchus xylophilus. Nematology 12, 225-233.

Dieterich, C. \& Sommer, R.J. (2009) How to become a parasite - lessons from the genomes of nematodes. Trends in Genetics 25, 203-209.

Felsenstein, J. (1985) Confidence limits on phylogenies: an approach using the bootstrap. Evolution 39, 783-791.

Fonseca, L., Lopes, A., Cardoso, J., Pestana, M., Abreu, F., Nunes, N., Mota, M. \& Abrantes, I. (2010). The pinewood nematode, Bursaphelenchus xylophilus, in Madeira Island. 30th International Symposium of European Society of Nematologists, 19-23 September, Vienna, Austria, p. 176 (abstracts).

Fuchs, A.G. (1937) Neue parasitische und halbparasitische Nematoden bei Borkenkafern und einige andere Nematoden. I. Teil. Zoologische Jahrbuecher Abteilung fuer Systematik Oekologie und Geographie der Tiere 70, 291-380.

Goellner, M., Smant, G., De Boer, J.M., Baum, T. \& Davis, E.L. (2000) Isolation of $\beta$-1,4-endoglucanase 
genes from Globodera tabacum and their expression during parasitism. Journal of Nematology 32, 154-165.

Gu, J., Braasch, H., Burgermeister, W., Brandstetter, M. \& Zhang, J. (2006) Description of Bursaphelenchus yongensis sp. n. (Nematoda: Parasitaphelenchidae) isolated from Pinus massoniana in China. Russian Journal of Nematology 14, 91-99.

Hall, T.A. (1999) BioEdit: a user-friendly biological sequences alignment editor and analysis program for Windows 95/98/NT. Nucleic Acids Symposium 41, 95-98.

Jones, J.T., Furlanetto, C. \& Kikuchi, T. (2005) Horizontal gene transfer from bacteria and fungi as a driving force in the evolution of plant parasitism in nematodes. Nematology 7, 641-646.

Kikuchi, T. (2008) Parasitism genes of pine wood nematode. pp. 67-80 in Zhao, B.G., Futai, K., Sutherland, J.R. \& Takeuchi, Y. (Eds) Pine wilt disease. Japan, Springer Press.

Kikuchi, T., Jones, J.T., Aikawa, T., Kosaka, H. \& Ogura, N. (2004) A family of glycosyl hydrolase family 45 cellulases from the pinewood nematode Bursaphelenchus xylophilus. FEBS Letters 572, 201-205.

Kikuchi, T., Aikawa, T., Kosaka, H., Pritchard, L., Ogura, N. \& Jones, J.T. (2007) Expressed sequence tag (EST) analysisof the pine wood nematode Bursaphelenchus xylophilus and B. mucronatus. Molecular and Biochemical Parasitology 155, 9-17.

Kikuchi, T., Cotton, J.A., Dalzell, J.J., Hasegawa, K., Kanzaki, N., McVeigh, P., Takanashi, T., Tsai, I.J., Assefa, S.A., Cock, P.J.A., Otto, T.D., Hunt, M., Reid, A.J., Sanchez-Flores, A., Tsuchihara, K., Yokoi, T., Larsson, M.C., Miwa, J., Maule, A.G., Sahashi, N., Jones, J.T. \& Berriman, M. (2011) Genomic insights into the origin of parasitism in the emerging plant pathogen Bursaphelenchus xylophilus. PLOS Pathogens 7 (9), e10022. doi:10.1371/journal.ppat.1002219.

Kimura, M. (1980) A simple method for estimating the evolutionary rate of base substitutions through comparative studies of nucleotide sequences. Journal of Molecular Evolution 16, 111-120.

Kiyohara, T. \& Bolla, R.I. (1990) Pathogenic variability among populations of the pinewood nematode, Bursaphelenchus xylophilus. Forest Science 36, 1061-1076.

Ma, H.B., Lu, Q., Liang, J. \& Zhang, X.Y. (2011) Functional analysis of the cellulose gene of the pine wood nematode, Bursaphelenchus xylophilus, using RNA interference. Genetics and Molecular Research 10, 1931-1941.

Madani, M., Subbotin, S.A., Ward, L.J., Li, X. \& De Boer, S.H. (2010) Molecular characterization of Canadian populations of potato cyst nematodes, Globodera rostochiensis and G. pallida using ribosomal nuclear RNA and cytochrome $b$ genes. Canadian Journal of Plant Pathology 32, 252-263.

Mota, M., Braasch, H., Bravo, M.A., Penas, A.C., Burgermeister, W., Metge, K. \& Sousa, E. (1999) First report of Bursaphelenchus xylophilus in Portugal and in Europe. Nematology 1, 727-734.

Picard, D., Sempere, T. \& Plantard, O. (2007) A northward colonisation of the Andes by the potato cyst nematode during geological times suggests multiple host-shifts from wild to cultivated potatoes. Molecular Phylogenetics and Evolution 42, 308-316.
Plantard, O., Picard, D., Valette, S., Scurrah, M., Grenier, E. \& Mugniéry, D. (2008) Origin and genetic diversity of Western European populations of the potato cyst nematode Globodera pallida inferred from mitochondrial sequences and microsatellite loci. Molecular Ecology 17, 2208-2218.

Robertson, L., Arcos, C.S., Escuer, M., Merino, S.R., Esparrago, G., Abelleira, A. \& Navas, A. (2011) Incidence of the pinewood nematode Bursaphelenchus xylophlius Steiner \& Buhrer, 1934 (Nickle, 1970) in Spain. Nematology 13, 755-757.

Rodrigues, J. (2008) Eradication program for the pinewood nematode in Portugal. pp. 5-14 in Mota, M. \& Vieira, P. (Eds) Pine wilt disease: a worldwide threat to forest ecosystems. The Netherlands, Springer Press.

Rosso, M.N., Favery, B., Piotte, C., Arthaud, L., De Boer, J.M., Hussey, R.S., Bakker, J., Baum, T.J. \& Abad, P. (1999) Isolation of a cDNA encoding a $\beta-1,4-$ endoglucanase in the root-knot nematode Meloidogyne incognita and expression analysis during plant parasitism. Molecular Plant-Microbe Interactions 12, 585-591.

Saitou, N. \& Nei, M. (1987) The neighbor-joining method: a new method for reconstructing phylogenetic trees. Molecular Biological Evolution 4, 406-425.

Smant, G., Stokkermans, J.P.W., Yan, Y., De Boer, J.M., Baum, T.J., Wang, X., Hussey, R.S., Gommers, F.J., Henrissat, B., Davis, E.L., Helder, J., Schots, A. \& Bakker, J. (1998) Endogenous cellulases in animals: isolation of $\beta$-1,4-endoglucanase genes from two species of plant parasitic cyst nematodes. Proceedings of the National Academy of Sciences of the United States of America 95, 4906-4911.

Southey, J.F. (1986) Laboratory methods for work with plant and soil nematodes. 202 pp. Ministry of Agriculture Fisheries and Food. London, Her Majesty's Stationary Office.

Steiner, G. \& Buhrer, E.M. (1934) Aphelenchoides xylophilus n. sp., a nematode associated with bluestain and other fungi in timber. Journal of Agricultural Research 48, 949-951.

Sutherland, J.R. \& Peterson, M. (1999) The pinewood nematode in Canada: history, distribution, hosts, potential vectors and research. pp. 247-253 in Futai, K., Togashi, K. \& Ikeda, T. (Eds) Sustainability of pine forests in relation to pine wilt and decline. Proceedings of the Symposium, 26-30 October 1998, Tokyo, Japan. Kyoto, Japan, Shokado Shoten.

Suzuki, K. (2002) Pine wilt disease - a threat to pine forest in Europe. Dendrobiology 48, 71-74.

Tamura, K. \& Nei, M. (1993) Estimation of the number of nucleotide substitutions in the control region of mitochondrial DNA in humans and chimpanzees. Molecular Biology and Evolution 10, 512-526.

Tamura, K., Peterson, D., Peterson, N., Stecher, G., Nei, M. \& Kumar, S. (2011) MEGA5: molecular evolutionary genetics analysis using maximum likelihood, evolutionary distance, and maximum parsimony methods. Molecular Biology and Evolution 28, 2731-2739.

Tomiczek, C., Braasch, H., Burgermeister, W., Metge, K., Hoyer, U. \& Brandstetter, M. (2003) Identification of Bursaphelenchus spp. isolated from Chinese 
packaging wood imported to Austria. Nematology 5, $573-581$.

Tomminen, J., Halik, S. \& Berglahl, D.R. (1991) Incubation temperature and time effects on life stages of Bursaphelenchus xylophilus in wood chips. Journal of Nematology 24, 477-484.

Valadas, V., Laranjo, M., Barbosa, P., Espada, M., Mota, M. \& Oliveira, S. (2012) The pinewood nematode, Bursaphelenchus xylophilus, in Portugal: possible introductions and spread routes of a serious biological invasion revealed by molecular methods. Nematology, in press. doi:10.1163/156854112X632673.

Vicente, C., Espada, M., Vieira, P. \& Mota, M. (2012) Pine wilt disease: a threat to European forestry. European
Journal of Plant Pathology, in press. doi 10.1007/s10658011-9924-x.

Vieira, P., Burgermeister, W., Mota, M., Metge, K. \& Silva, G. (2007) Lack of genetic variation of Bursaphelenchus xylophilus in Portugal revealed by RAPD-PCR analyses. Journal of Nematology 39, 118-126.

Xie, B.-Y., Cheng, X.-Y., Shi, J., Zhang, Q.-W., Dai, S.-M., Cheng, F.X. \& Luo, Y.-Q. (2009) Mechanisms of invasive population establishment and spread of pinewood nematodes in China. Science in China Series C: Life Sciences 52, 587-594.

Zhao, B. \& Lin, F. (2005) Mutualistic symbiosis between Bursaphelenchus xylophilus and bacteria of the genus Pseudomonas. Forest Pathology 35, 339-345. 